Journal of Al-Azhar University Engineering Sector

Vol.15, No. 55, April, 2020, 459-474

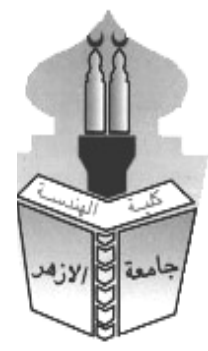

\title{
AMBIENT VIBRATION TEST AND NUMERICAL MODELLING OF WIND TURBINE TOWERS INCLUDING SOIL STRUCTURE INTERACTION
}

\begin{abstract}
Due to The rapid expansion of energy and growing number of wind turbines construction in earthquake areas, a design method for simple and accurate evaluation of seismic load to ensure structural integrity is required. In Egypt, there are some appropriate places to build wind turbine towers lie in active seismically regions, so accurate analysis is necessary for prediction of seismic loads with consideration of intensity of the earthquake, soil and structural charateristics.In this research, seismic behavior of wind turbine towers Gamesa Type G52 in Zafarana Wind Farm Egypt is investigated using experimental work by ambient vibration test, and fully dynamic analysis based on time history from El Aqaba Earthquake 1995 using 3D by PLAXIS 3D software, including the soil structure interaction effect. The results obtained from dynamic analyses are discussed. From this study it is concluded that, the fully dynamic seismic analysis based on used PLAXIS 3D with the aid of the full scale ambient vibration test gives almost good simulation for the seismic loads that can be applied to wind turbine tower design in Egypt.
\end{abstract}

\section{KEYWORDS: Wind Turbine, Zafarana Wind Farm, Gamesa Type G52 Wind Turbine, Ambient Vibration Test, Numerical Modelling, PLAXIS 3D Software.}

$$
\begin{aligned}
& \text { اختبار الاهتزاز غير المحيط والتحليل العدي ثُلاثي الإبعاد لتوربينات الرياح ويشمل رد فعل التربة }
\end{aligned}
$$

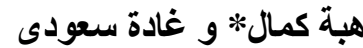

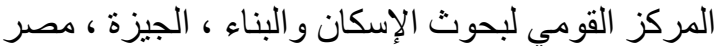

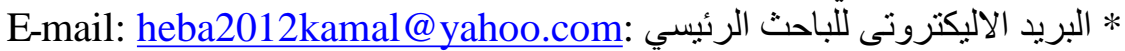

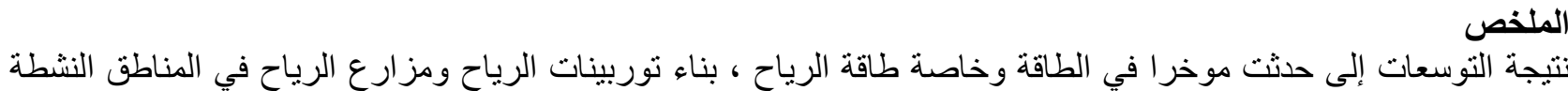

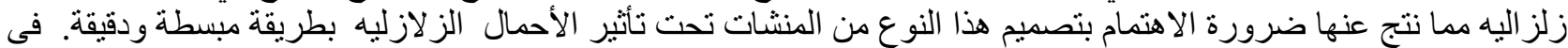

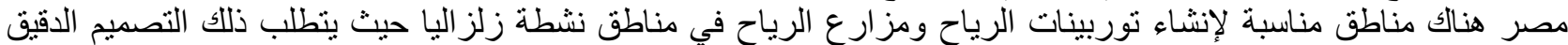

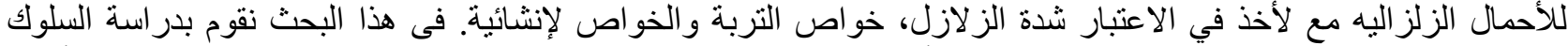

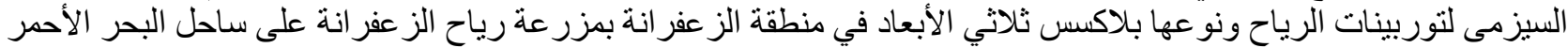

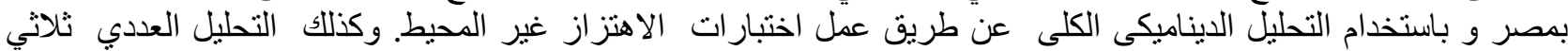

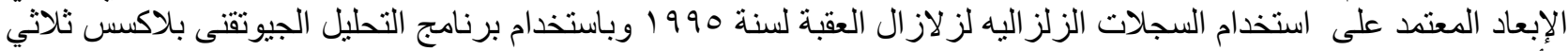

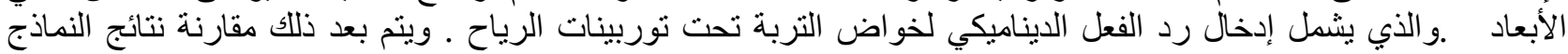

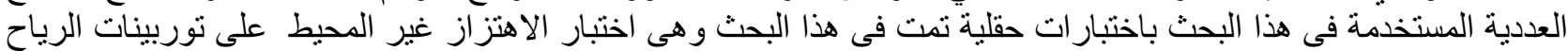

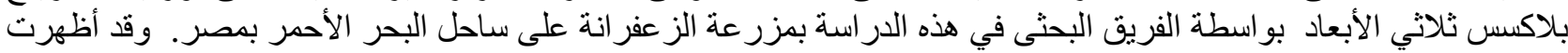

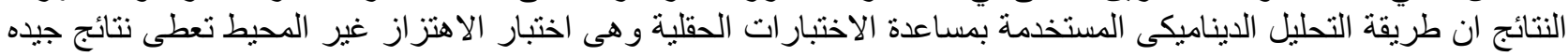

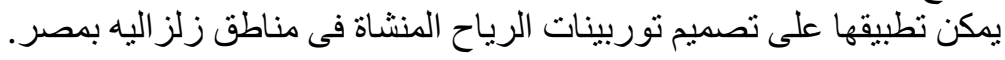




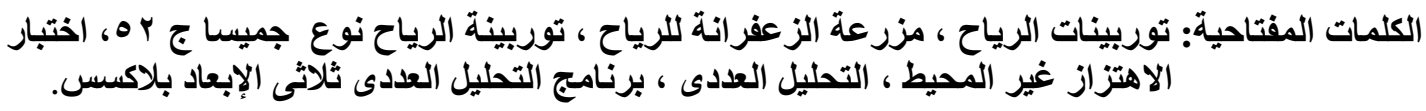

\section{INTRODUCTION}

Zafarana Wind Farm is located $120 \mathrm{~km}$ south of the Suez on the Red Sea. It's a location has the advantage with extreme wind conditions, and the wind turbines installed there were specially prepared to cope with Egypt's hot desert climate, sand storms and salty air. Special seals had been created to prevent sand from getting into the units, and rotor-blade cleaning was planned several times per year. The wind turbines at Zafarana Wind Farm were produced by Danish Vestas, German Nordex and Spanish Gamesa. The installation was carried out under the banner of the Egyptian New and Renewable Energy Agency (NREA). Wind Farm currently has a generating capacity of $517 \mathrm{MW}$, as one of the largest onshore wind farms in the world. Figure (1) shows the location and layout of all wind turbines at Zafarana Wind Farm. Zafarana. It is located in an active seismic zone along the west side of the Gulf of Suez. Accordingly, fully dynamic analysis of wind turbine towers is required. Where, the current Egyptian design codes lack the provisions of both wind and seismic design loadings for wind turbine towers. Also, an extension of the wind farm south of Zafarana Wind Farm is under consideration for construction in the near future. There are three types of wind turbines, as follows:

1.Nordex wind turbine N43/600 kW: It has a three-bladed rotor, mounted upwind of the tower. The power limitation is carried out by stall regulation.

2.Vestas wind turbine V47-660 kW: It is standardly delivered with a single generator, which is highly efficient in the vast majority of wind conditions.

3.Gamesa wind turbine G52-850 kW: This turbine provides optimum performance for medium and high winds, class IA, for high wind sites. The pitch and variable speed technology maximize energy production. In this research, seismic behavior of wind turbine towers Gamesa Type G52 in Zafarana Wind Farm Egypt is investigated using experimental work by ambient vibration test and work using fully dynamic analysis based on time history from El Aqaba Earthquake 1995 by 3D PLAXIS software, and including the soil structure interaction effect. Results obtained from dynamic analyses are discussed.

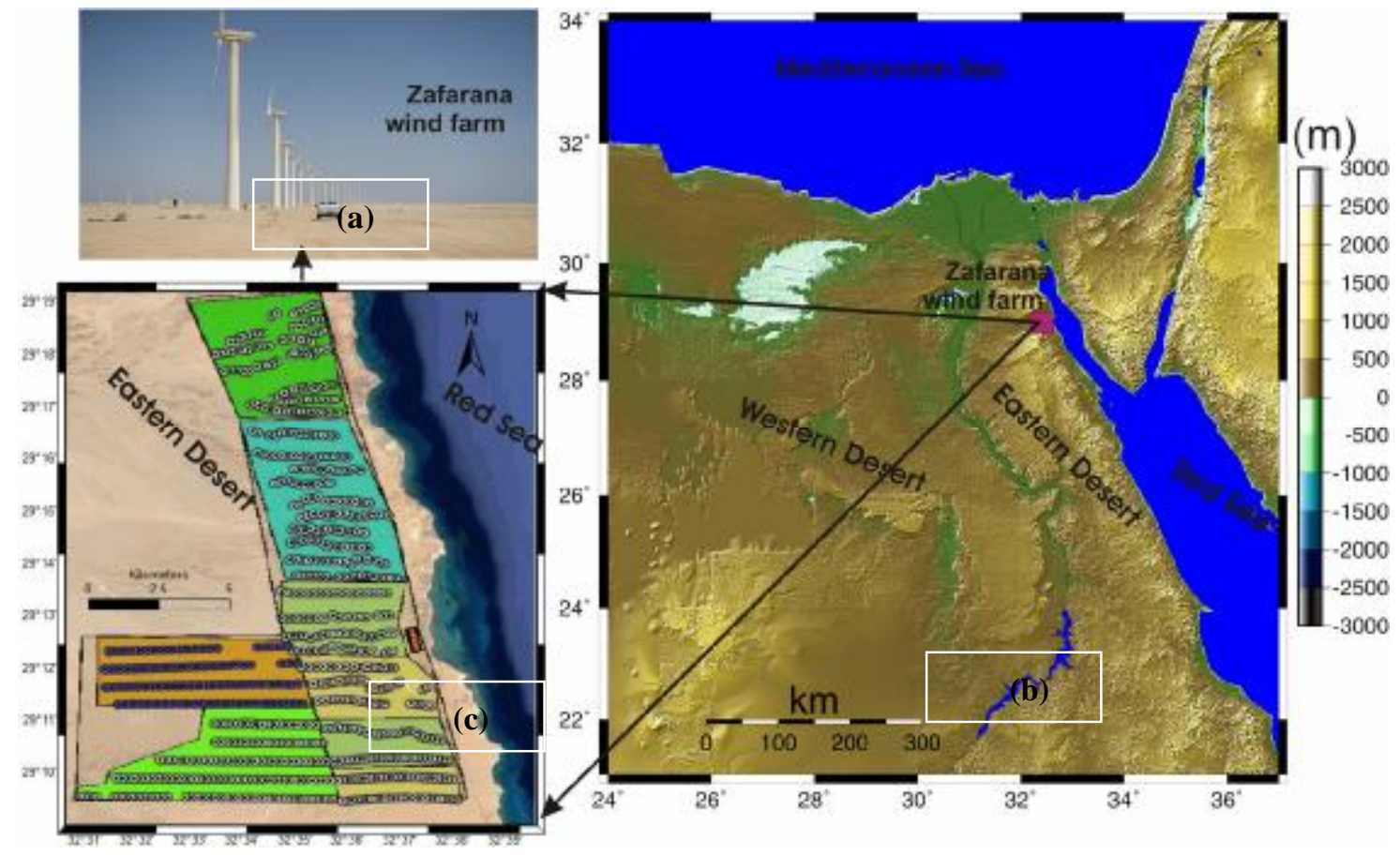

Figure (1) (a) topographic map of Egypt and the Zafarana Wind Farm location. (b) satellite image of Zafarana Wind Farm. (c) photo of the wind turbine towers in Zafarana Wind Farm 


\section{ZAFARANA WIND TURBINES FARM}

The Zafarana Wind Farm is located $120 \mathrm{~km}$ south of the Suez on the Red Sea at E32 35' 45", N29 13' 42". The tectonics in this region is related to the movement between the African, Eurasian and Arabian plates [1,2,3]. Earthquake is a Motion of ground surface as result of wave energy transmitted through surface layers of Earth. Due to sudden slips along faults, strains build up between 2 plates or 2 rock blocks on either side of fault. Strain can be released slowly (fault creep) or quickly (earthquake). Seismic activity generally occurs within vicinity of lithospheric plate boundaries [2,3]. The location of Zafarana wind farm is in an active fold as an earthquake zone. A seismicity map in and around Zafarana Wind Farm from 1900 to 2012 is shown in Figure (2) [1]. therefore, it is necessary to study the zone seismicity and its effect on existing and future wind farm projects.

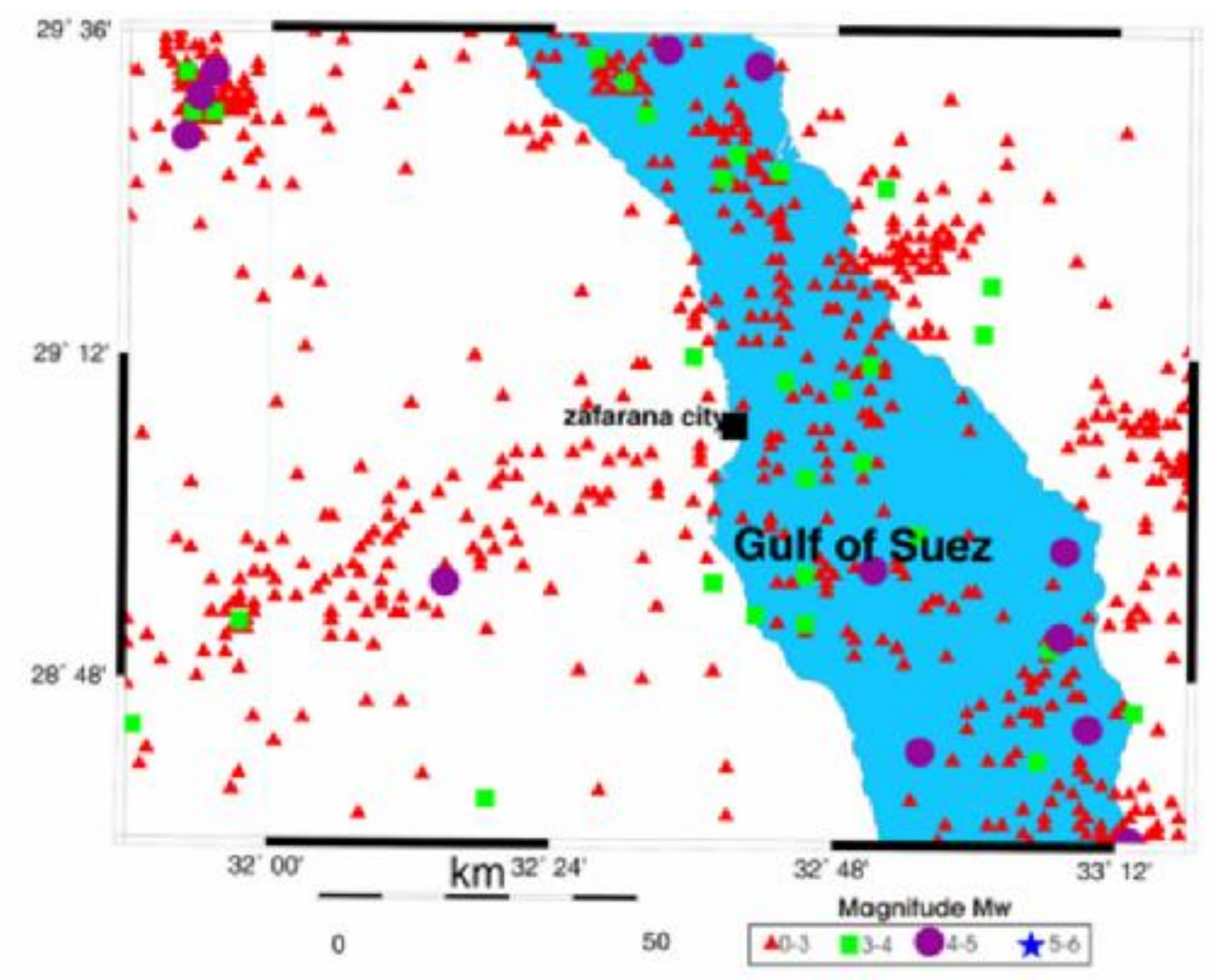

Figure (2) Seismicity map in and around Zafarana Wind Farm from 1900 to 2012 [1]

\section{ZAFARAN EARTHQUAKE}

\subsection{Zafarana Earthquake Zones}

The Egyptian code for loads version 2012 divides Egypt into five main zones according to the seismic impact [4]. Figure (3) presents the seismic zones considering the assumed returned time of earthquake is 475 year. From this Figure, Zafarana wind farm is located at the coast of the Gulf of Suez at the red zone. According to the colored scale at the right of the map, the red zone represents the third zone. So the design ground acceleration is taken as $0.15 \mathrm{~g}$. (The ground acceleration is considered $9.81 \mathrm{~m} / \mathrm{s}^{2}$ )

$a_{g}=0.15 g=1.47 \mathrm{~m} / \mathrm{s}^{2}$ 


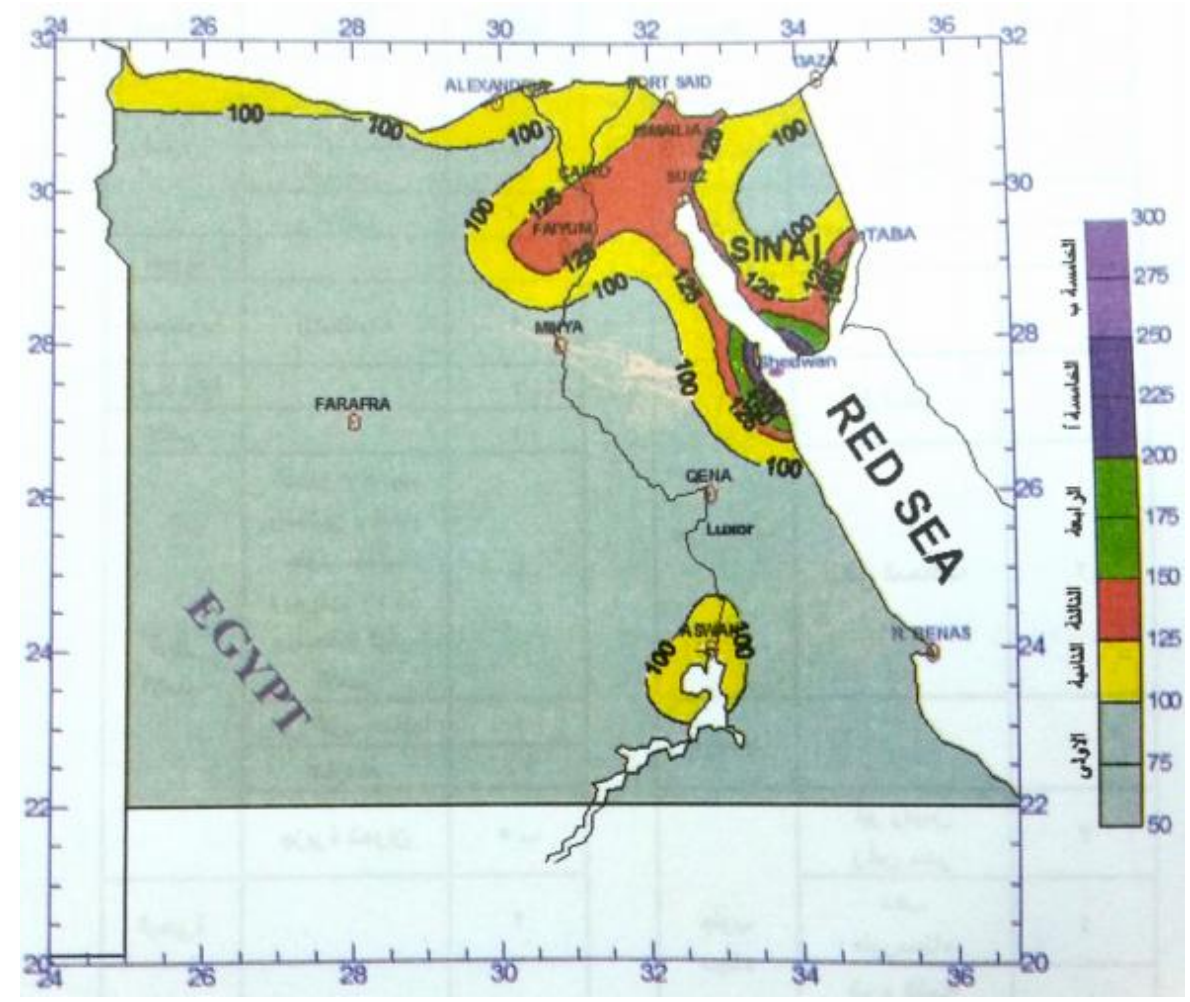

Figure (3) Seismic impact zones [4]

\subsection{Zafarana Time History El Ababa Earthquake For Fully Dynamic Analysis}

Since there isn't a recorded time histories for Zafarana wind farm area, a circle of $300 \mathrm{~km}$ radius around the site is taken in order to obtain a time history from earthquakes happened among this area [2]. On 22 November 1995, the largest earthquake instrumentally recorded in the area, with magnitude $\mathrm{Mw}$ 7.3, occurred in the Gulf of Aqaba. The ground motion of Al Aqaba Earthquake 1995 as recorded at Eilat Station is used in this study. The measured acceleration time history is recorded at surface. Figure (4) shows the time histories of $\mathrm{Al}$ Aqaba Earthquake 1995 at surface used in this study.

\section{SOIL UNDERLAYING WIND TOWERS}

The geological features indicate that, the study area consists of coastal and wadi deposits. Based on the results of the previous site investigation and laboratory testing the soil formations encountered in the boreholes show five main formations, which are: Wadi deposits, Clay, Claystone, Sand and Sandstone. Groundwater is not encountered in any of the boreholes at the time of investigation to depth of $20 \mathrm{~m}$ and the foundation depth is $2.50 \mathrm{~m}$.

The Egyptian code for loads classifies the soil underneath the foundation into five categories (A, B, C, D and E) based on the results of SPT test. According to the previous soil profile, SPT results indicate a very dense formation. However, all of the SPT results were affected by the cementation of the sand and reached refusal values. Category (A) represented rock or formations like rock have a very high SPT results. So the soil category at Zafarana wind farm is taken as category (A). 

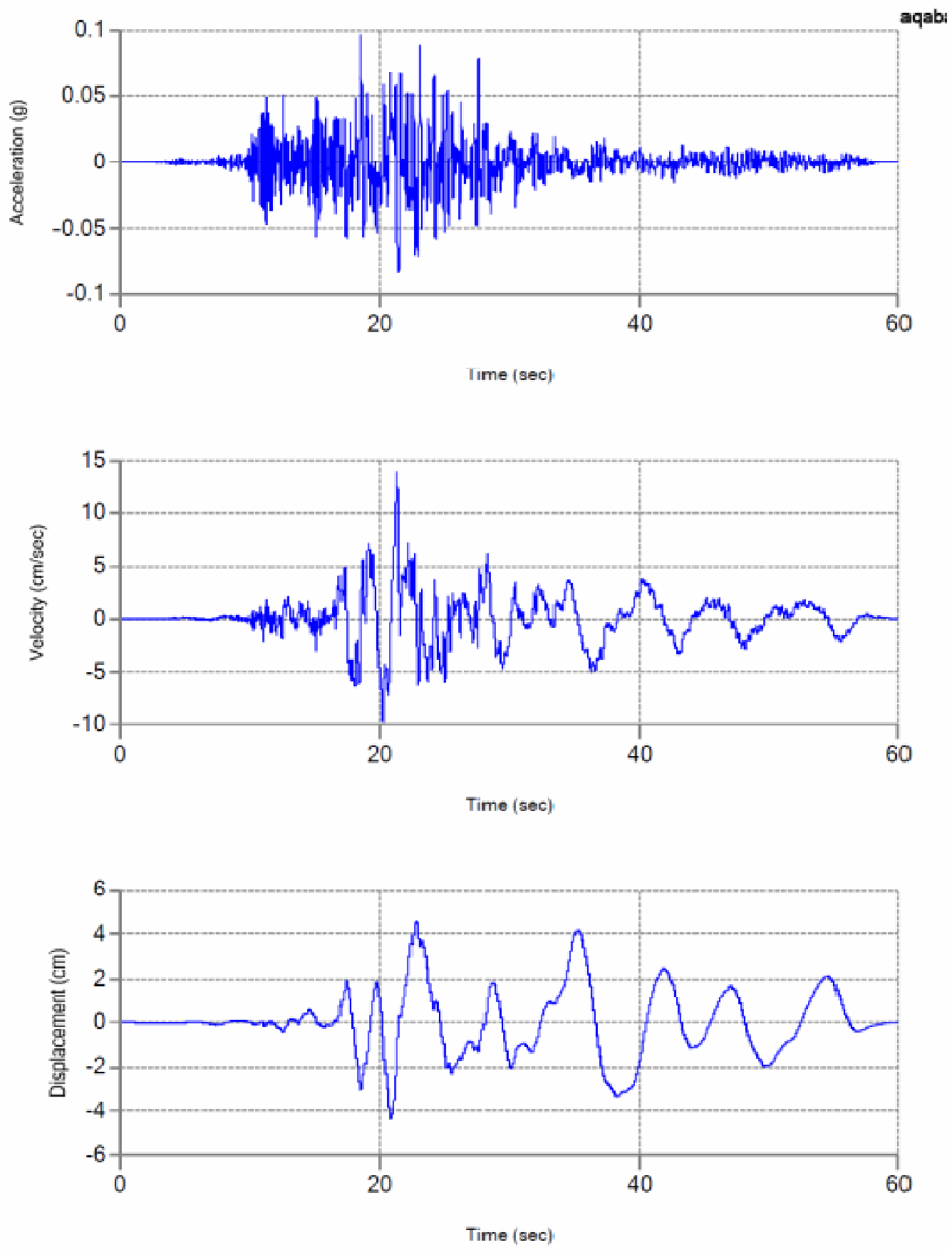

Figure (4) Time histories of Aqaba earthquake in 1995

\section{GAMESA WIND TURBINE TOWER}

The Gamesa G52 is 3 bladed, horizontal-axis wind turbine with 55 meter rotor diameter, as shown in Figure (5). Tubular towers made of steel are constructed by rolling flat steel plates to the desired diameter and welding to join. The supporting tower is a steel conical tower with height of $55 \mathrm{~m}$ which consists of two sections. The top and bottom tower diameters are $3.0 \mathrm{~m}$ and $6.0 \mathrm{~m}$; respectively. The thickness of the tower is $2.1 \mathrm{~cm}$. The complete Nacelle weight (including gearbox and generator, rotor hub) is $430 \mathrm{kN}$. So the total weight mounted at the top of the tower is approximately $620 \mathrm{kN}$. Figure (5) shows Typical Gamesa G52 wind turbine tower at Zafarana wind farm (6). Figure (6) shows the layout of Zafarana wind farm (6), where one of the GamesaG52 was selected for ambient vibration field and numerical modelling . 
AMBIENT VIBRATION TEST AND NUMERICAL MODELLING OF WIND TURBINE TOWERS INCLUDING SOIL STRUCTURE INTERACTION

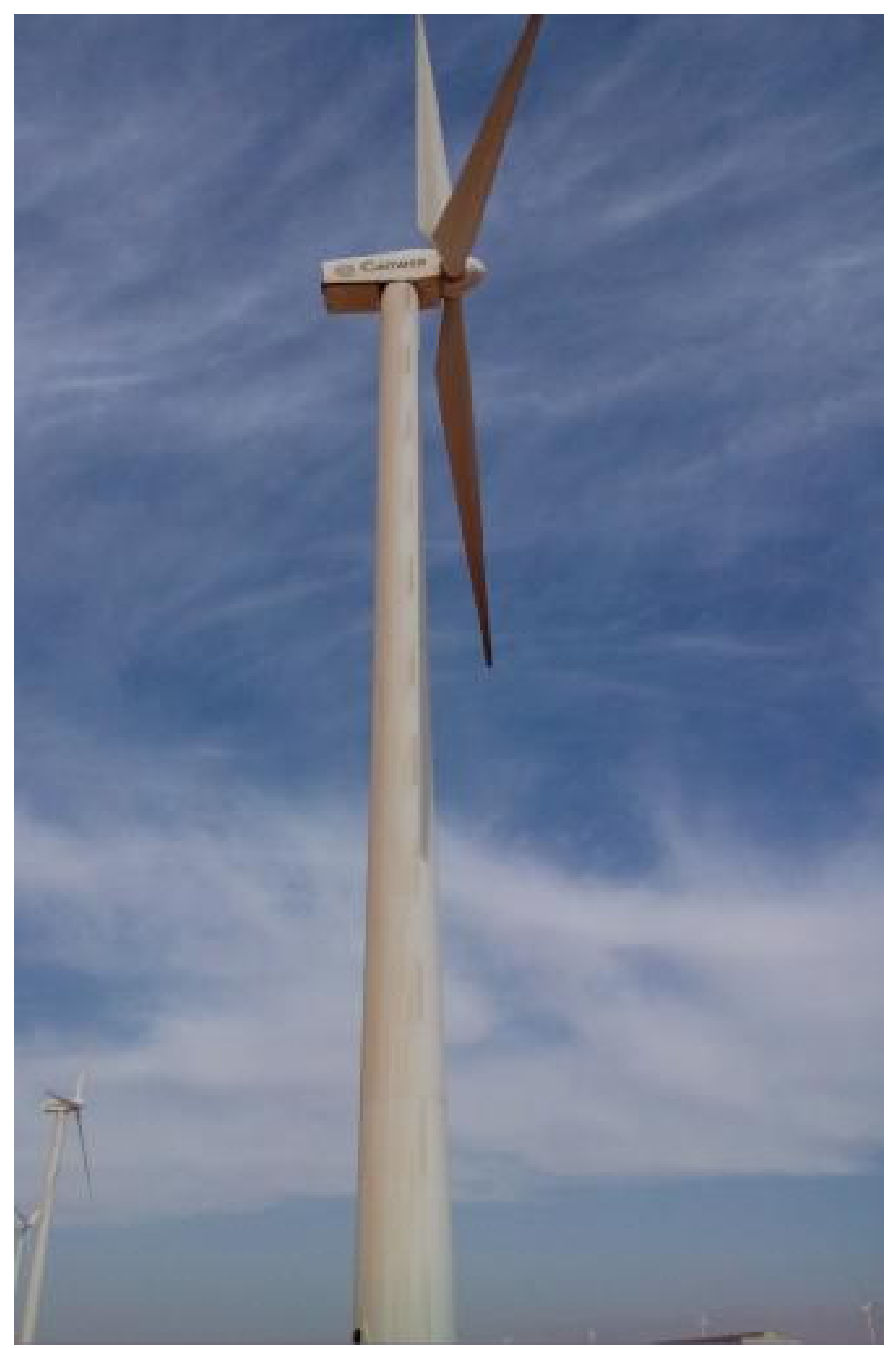

Figure (5) Gamesa G52 wind turbine towers at Zafarana (6) Wind Farm

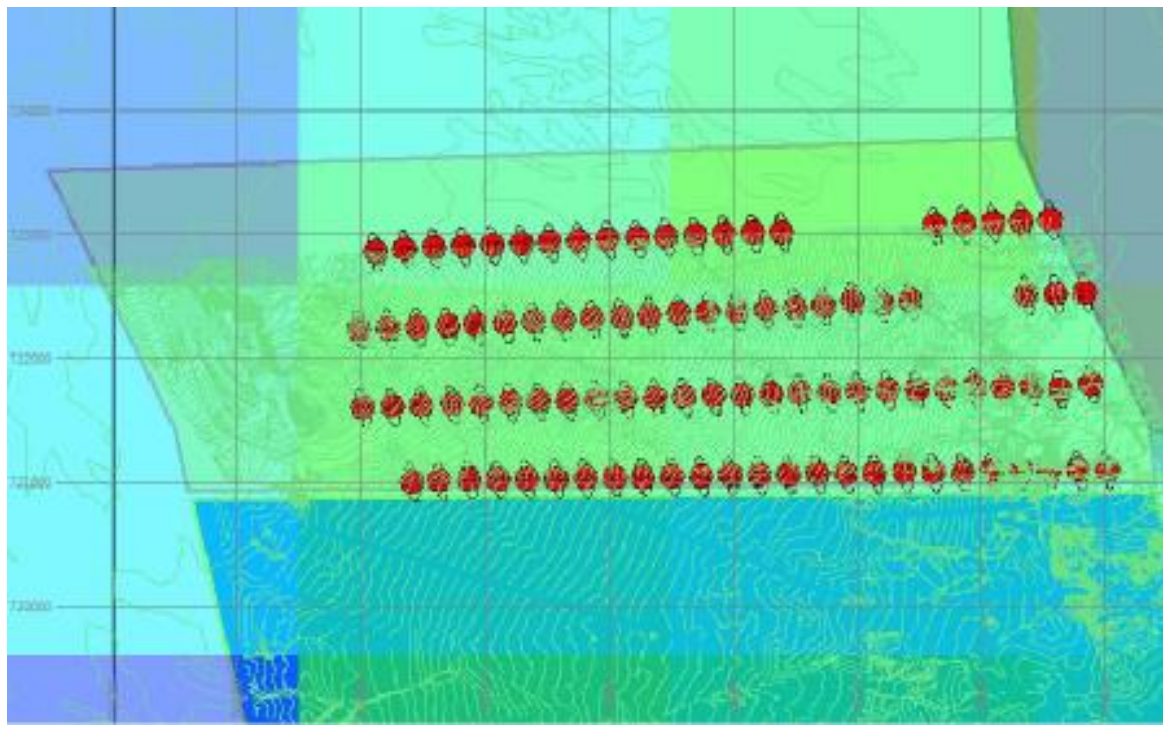

Figure (6) Layout of Zafanara (6) and the selected tower for dynamic testing and numerical modelling 


\section{AMBIENT VIBRATION TESTING AND MODAL IDENTIFICATION}

\subsection{Ambient Vibration Testing and Signal Processing}

The ambient vibration test was performed using a 18-channel data acquisition system consists of three B\&K LAN-XI and 18 PCB 393B40 uni-axial piezoelectric accelerometers as shown in Figure (7) $[5,6]$. The locations of the accelerometers at the test points are shown in Figure (8). PCB 393B40 accelerometers have a sensitivity of $1000 \mathrm{mV} / \mathrm{g}$, a measurement range of \pm $5 \mathrm{~g}$ and frequency range 0.06 to $450 \mathrm{~Hz}$. B\&K LAN-XI system is a portable data acquisition unit with six input channels. LAN-XI data acquisition modules were distributed over the height of the tower and connected to a network switch with a single LAN cable each $[5,6]$. This supplies both power and assures perfectly sample-synchronized data acquisition where cable work is significantly reduced. The ambient response of the tower was recorded for 30 min at sampling frequency $800 \mathrm{~Hz}$. It took about 7 hours for Gamesa G52 tower to finish the test settings applied to capture both the bending and the torsional modes. For Gamesa G52 tower, one setup using 18 channels was set to capture the bending modes, other setup of 12 channels was applied to capture the torsion modes [7,8,9] as shown in Figure (8). The arrangement of the accelerometers in test setup of Gamesa G52 tower is shown in Figure (9). It should be noted that the space confined by the internal ladder and the tower wall behind it was the available accessible working area for the team during the test as shown in Figure (10). As implemented in ARTeMIS, post-processing analysis was performed. The signal data were further decimated in time by a factor 10, giving a baseband for the analysis ranging to $40 \mathrm{~Hz}$. The recorded data was processed in frequency domain. Power Spectral Density (PSD) was estimated using total time period with a frame of 8192 data points. Hanning windows are applied with $66.7 \%$ overlapping by default. 4096 spectrum lines, with frequency resolution of $0.01 \mathrm{~Hz}$, were obtained $[7,8,9]$.

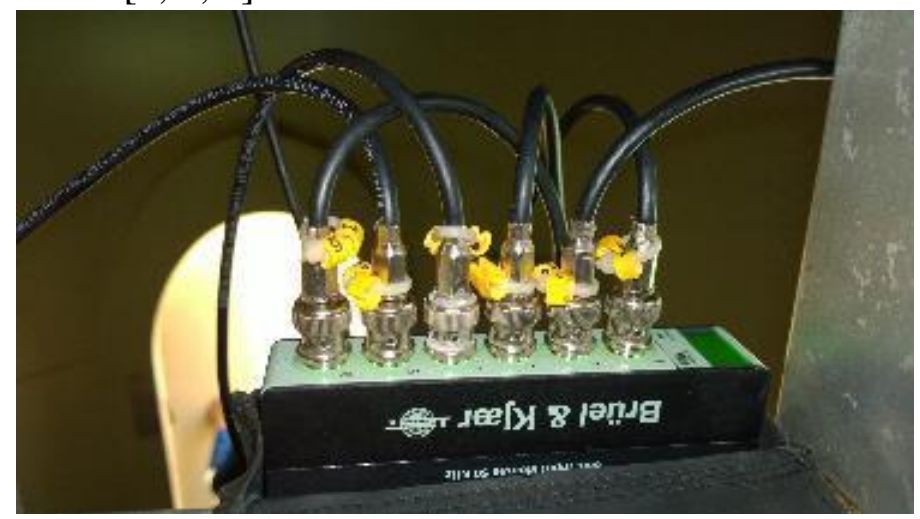

LAN-XI unit attached to the ladder

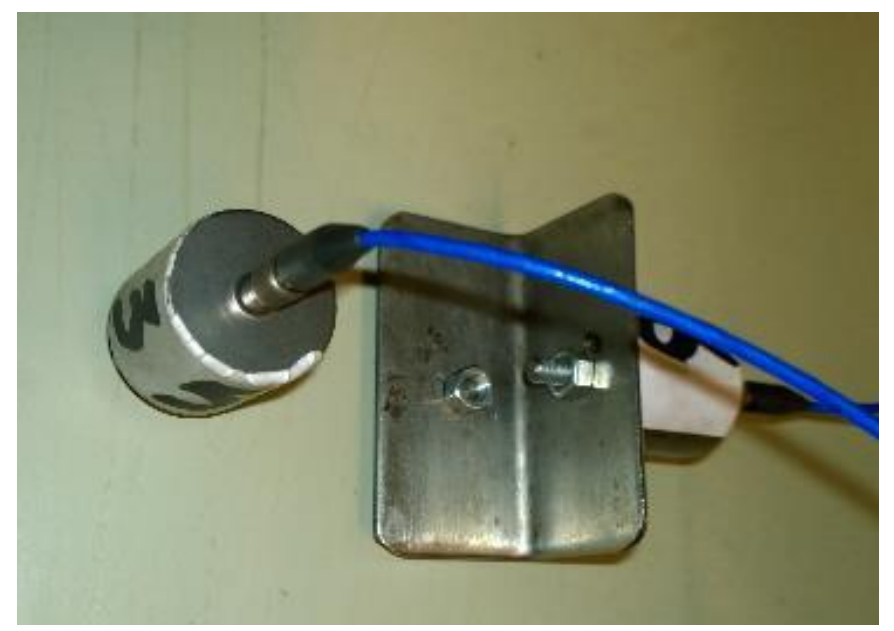

PCB accelerometers with magnetic mounting attached to the tower wall

Figure (7) Test equipment 
AMBIENT VIBRATION TEST AND NUMERICAL MODELLING OF WIND TURBINE TOWERS INCLUDING SOIL STRUCTURE INTERACTION
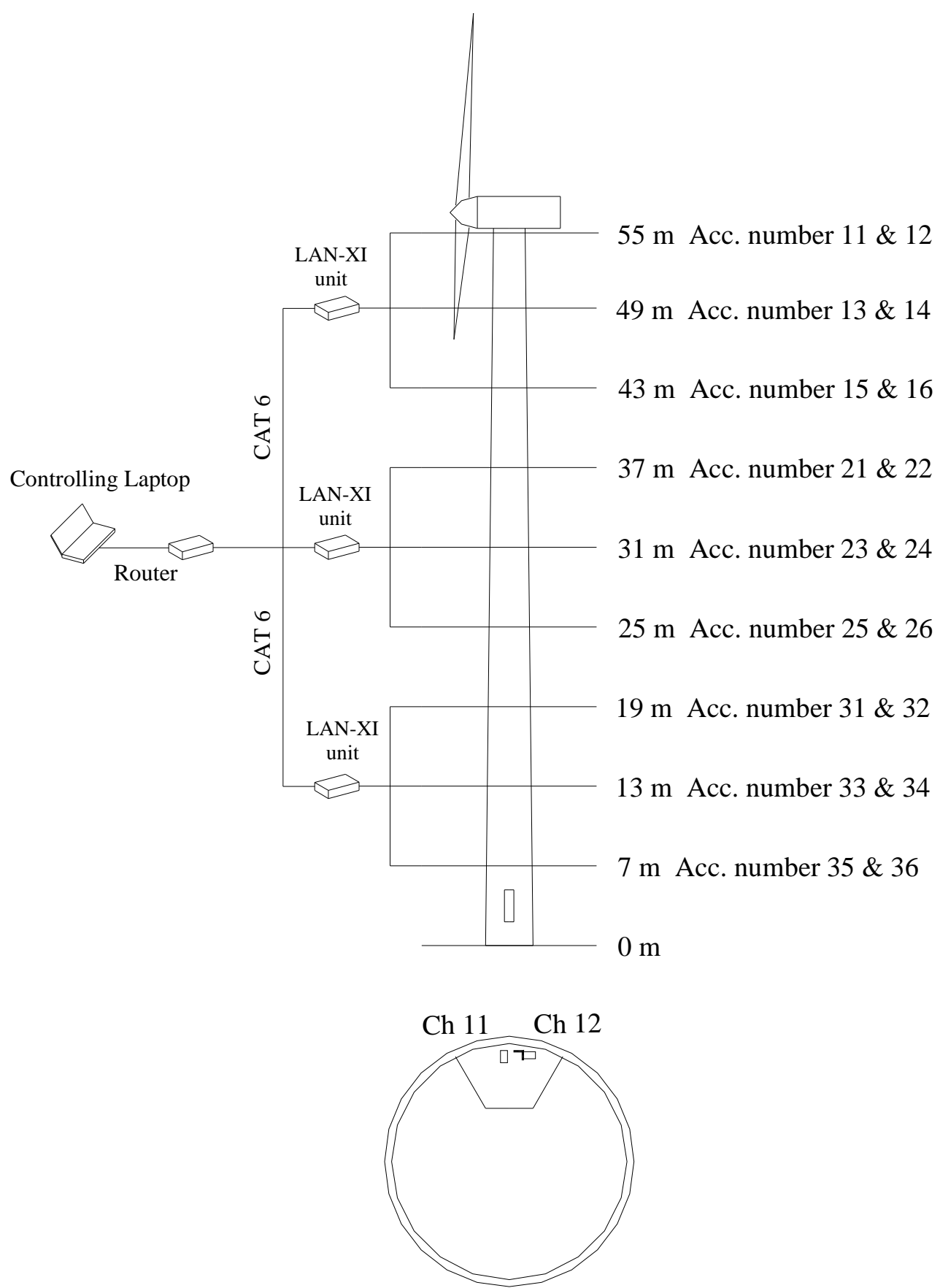

Plan view typical view with accelerometer locations

Figure (8) Test setup for dynamic testing 


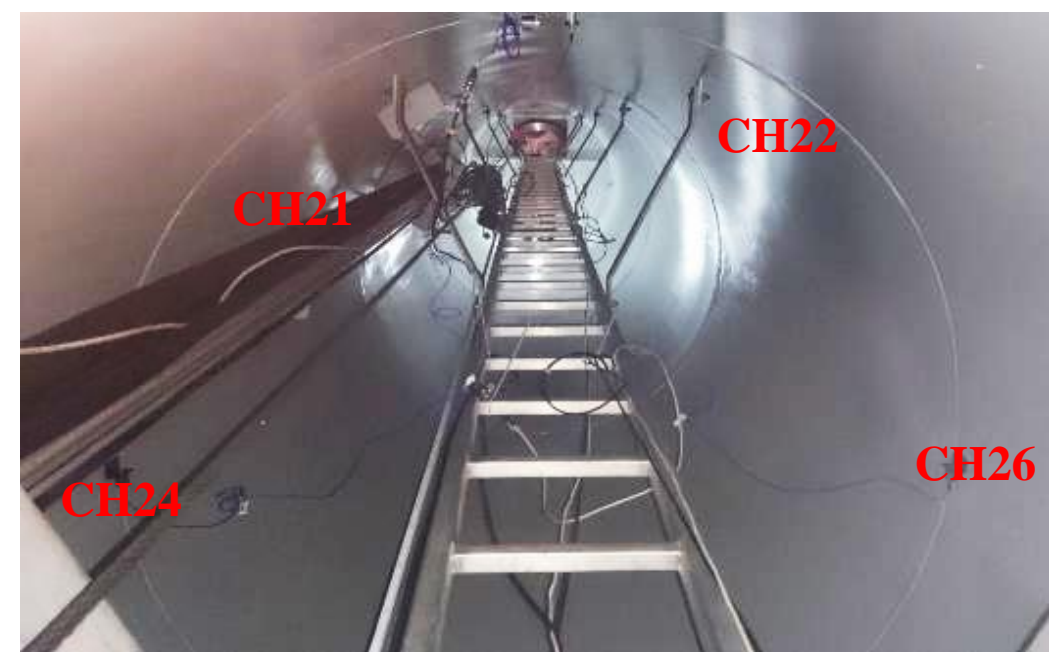

Figure (9) Accelerometers arrangement at level 2 for Gamessa G52 Test Setup

\subsection{Modal Identification}

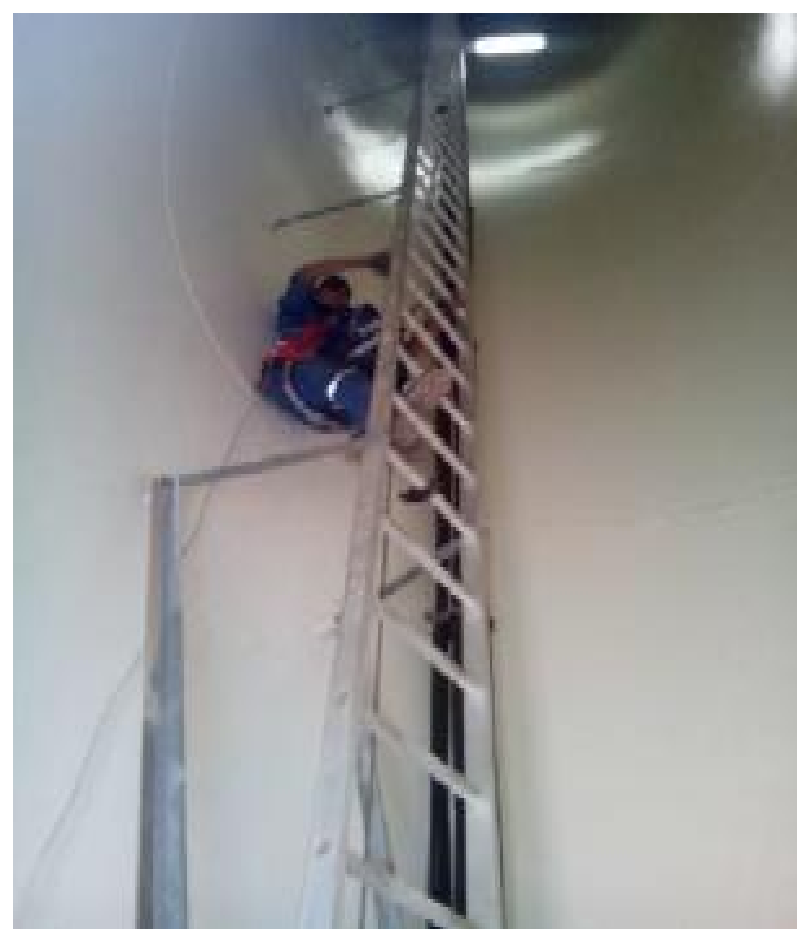

Figure (10) Working accessible space inside the tower

The Enhanced frequency domain decomposition (EFDD) method adds a modal estimation layer to frequency domain decomposition (FDD) method $[7,8,9]$. In the method, modes are selected by peak-picking located in singular value decomposition plots (SVD) calculated from the spectral density spectra of the responses. The single degree of freedom (SDOF) function is estimated using the shape determined by the previous FDD peak picking - the latter being used as a reference vector in a correlation analysis based on the Modal Assurance Criterion (MAC). A MAC value is computed between the reference FDD vector and a singular vector for each particular frequency line. If the MAC value of this vector is above a user-specified MAC Rejection Level, the corresponding singular value is included in the description of the SDOF function. In EFDD method, SDOF power spectral density (PSD) function, identified around a peak of resonance, is taken back to the time domain using the inverse discrete Fourier transform (IDFT). The natural frequency is obtained by determining the number of zero-crossing as a function of time, and the damping by the logarithmic decrement of the corresponding SDOF normalized auto correlation function. 
Modal models are estimated for the different state space dimensions up to a selected maximum state space dimension $[7,8,9]$. The setting of maximum state space dimension depends upon the number of modes, which is searched for, the excitation, the number of sinusoidal components in the response signals and the number of noise modes needed to fit (predict) the measured response signals. The results are achieved by a singular value decomposition of the full observation matrix, which is a matrix calculated from the measured responses, and extracting a subspace holding the modes in the model. A stabilization diagram for the modal models is used for selecting a model (at a certain state space dimension). If the responses are measured in a sequence of measurements (data sets), a number of reference Degrees of Freedom (DOF's) must be included in each measurement (data set) and the models from each measurement are linked together afterwards. Applying the modal identification methods in ARTeMIS [10], The analysis produced the singular values plots (SVP) as shown in Figure (11). For the same tower, it is clear that, identical modal peaks were produced from analysing the tower response for test setup using EFDD. SSI method consumed a lot of time and effort to manually obtain the structural modes of the towers. The automatic estimation option of SSI-CVA identification in ARTeMIS [10] successfully identified the first side to side bending mode of Gamesa tower as shown in Figure (12) that could not be detected by EFDD. This specific mode is at $0.259 \mathrm{~Hz}$. For a steel flexible stucture with first natural frequency less than $1 \mathrm{~Hz}$, SSI technique is shown to be powerful to clearly identify it. As the Gamesa tower is taller and it exhibited torsion bending coupled modes. Both towers revealed a dynamic behavior of close bending modes at the lower frequency range. For Gamesa G52 tower 11 structural modes were successfully determined in the range $0-25 \mathrm{~Hz}$. The modal results for Gamesa G52 towers are displayed in Figure (13).

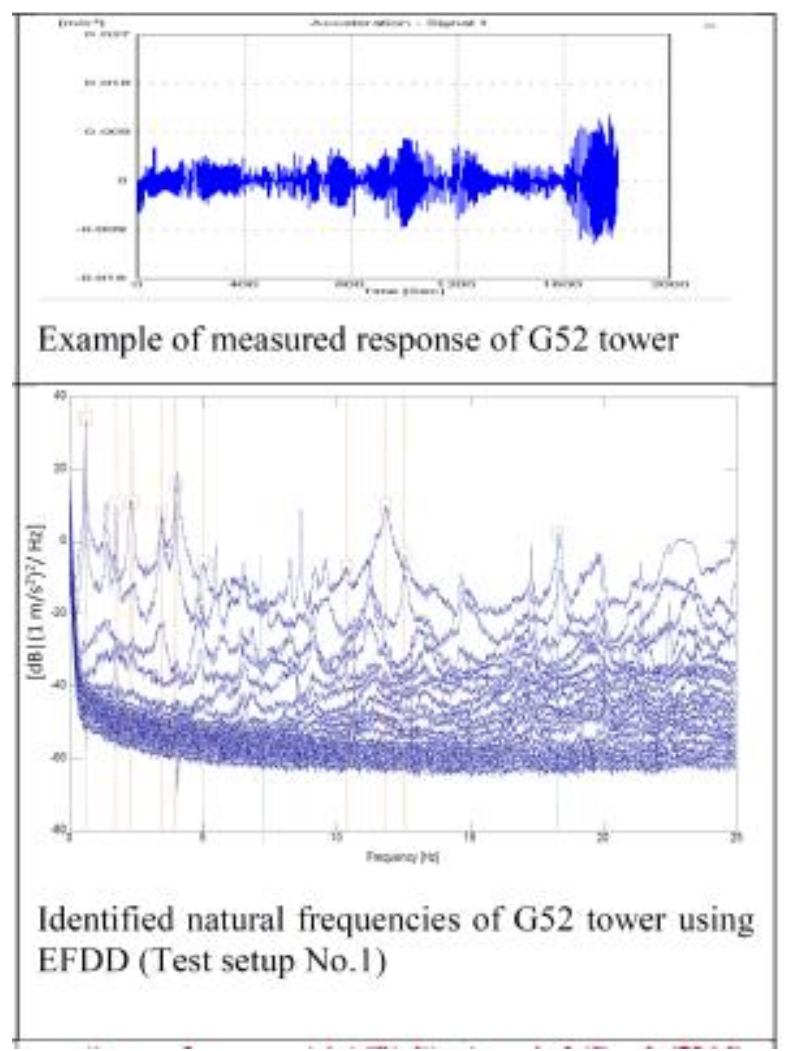

Figure (11) Modal identification analysis of Gamesa G52 Wind Turbine Tower 
AMBIENT VIBRATION TEST AND NUMERICAL MODELLING OF WIND TURBINE TOWERS INCLUDING SOIL STRUCTURE INTERACTION

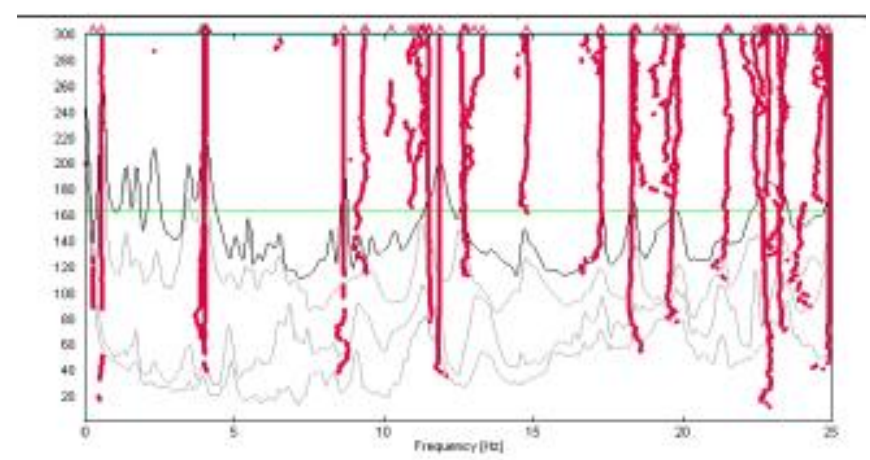

Stabilization diagram of G52 tower response

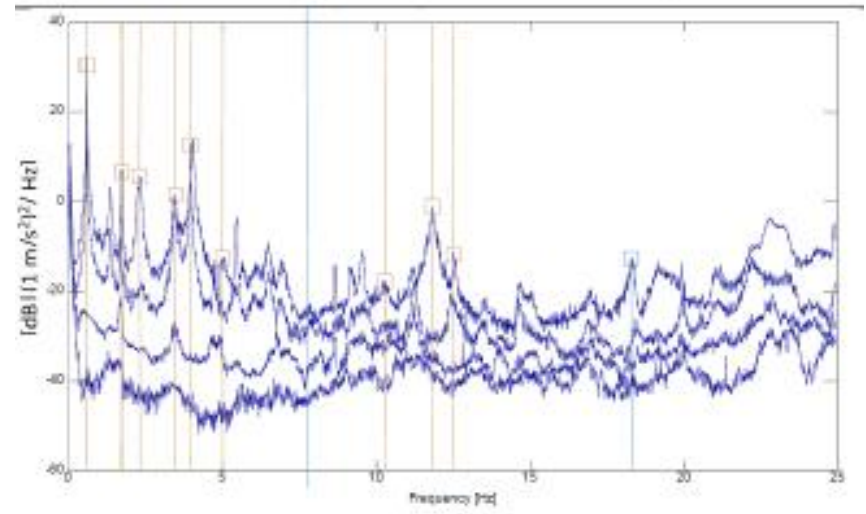

Identified natural frequencies of G52 tower using EFDD (Test setup No.2)

Figure (11) Modal identification analysis of Gamesa G52 Wind Turbine Tower (Continued)

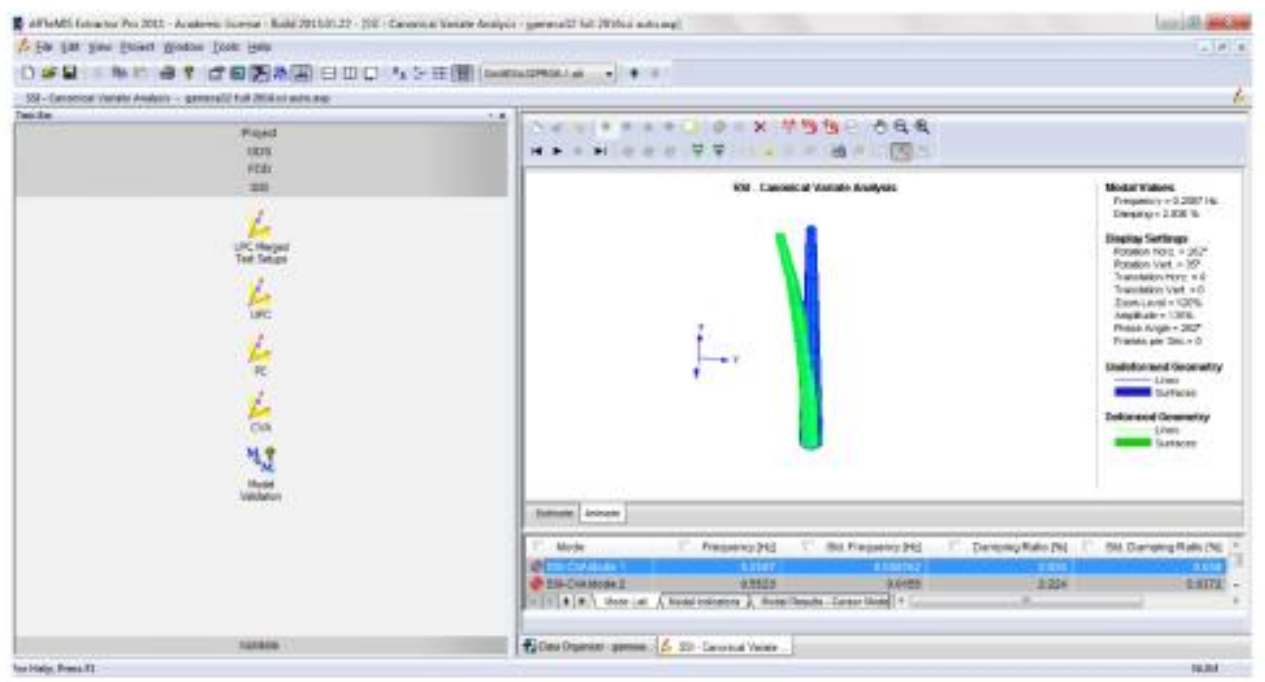

Figure (12) Identified side to side bending mode using automatis estimation SSI-CVA 


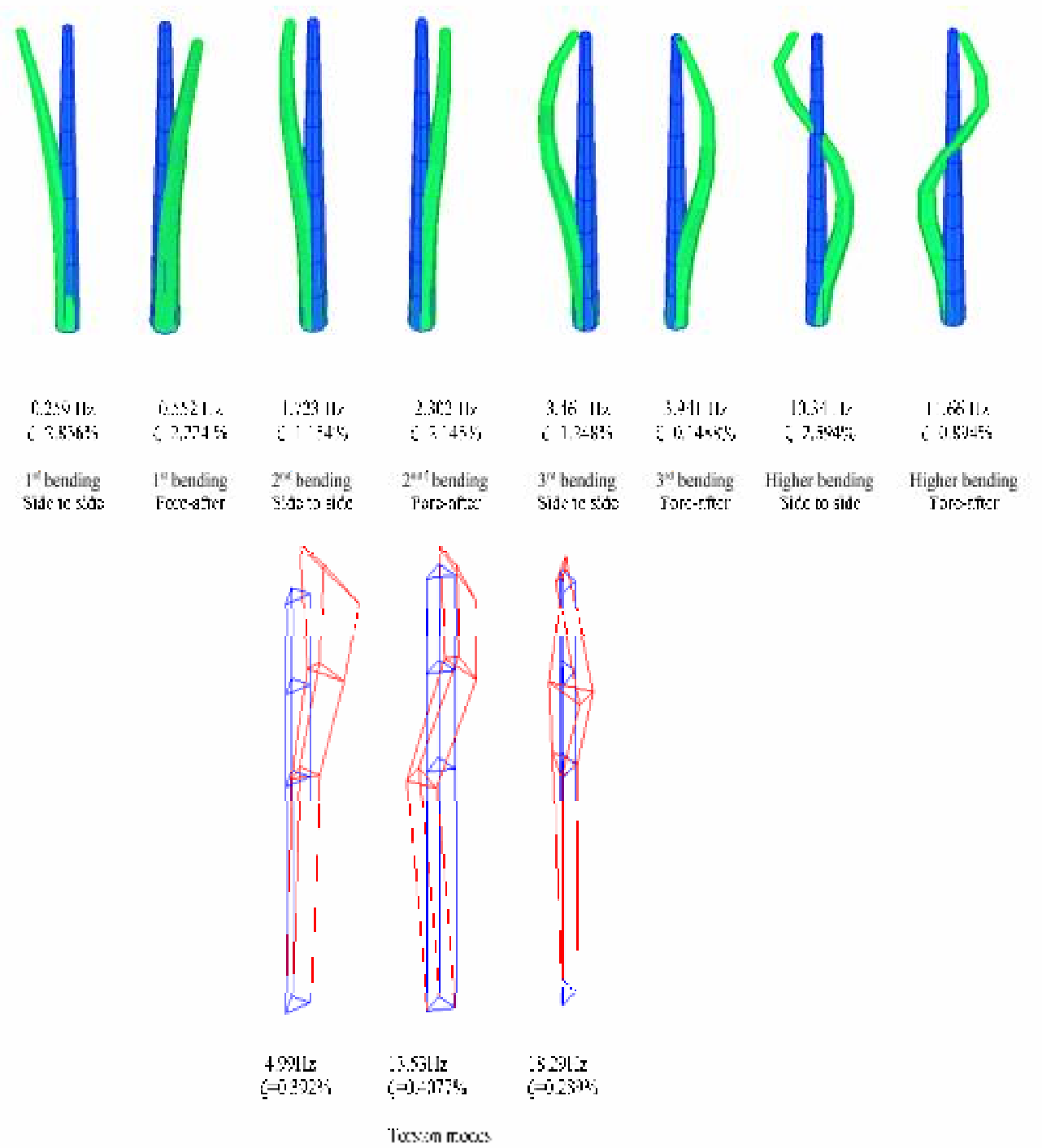

Figure (13) Identified structural modes of G52 wind turbine tower

\section{FULLY DYNAMIC ANALYSIS USING 3D MODELLING AND TIME HISTORY ANALYSIS}

\subsection{Numerical model of Soil-Structure Interaction in PLAXIS 3D}

PLAXIS 3D is a three-dimensional finite element program, developed for the analysis of deformation, stability and groundwater flow in geotechnical engineering. The program is supplied as an extended package, including static elastoplastic deformation, advanced soil models, stability analysis, consolidation and safety analysis. Moreover, the Dynamics module can be used in PLAXIS to analyze vibrations in the soil and their influence on nearby structures [11].

According to the finite element method, a continuum is divided into a number of (volume) elements. Each element consists of a number of nodes. Each node has a number of degrees of freedom that correspond to discrete values of the unknowns in the problem to be solved. In PLAXIS 3D, the soil continuum is divided into 10-node tetrahedral elements. This type of element provides a second-order interpolation of displacements. It contains four (4) corner nodes in addition to six (6) more nodes at the mid-point of each side as seen in Figure (14) [11]. 


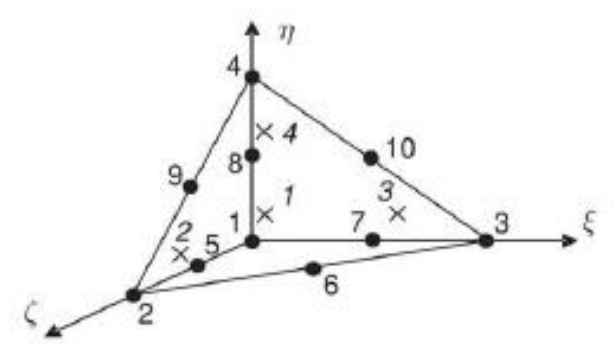

Figure (14) 10-Node Tetrahedral Elements Used in Soil Discretizing

PLAXIS 3D contains many constitutive models designed to simulate the behavior of the soil. The model chosen for the current analysis is the Mohr-Coulomb model. Mohr- Coulomb model is a perfectly plastic constitutive model with a fixed yield surface that is fully defined by model parameters and not affected by plastic straining [11].

The body of the wind turbine and its foundation are modeled in PLAXIS using plate elements. Plates are two-dimensional linear elastic objects used to model thin structural elements. During the meshing operation, plate elements are discretized into 6-node triangles with six degrees of freedom per each node as seen in Figure (15) [11].

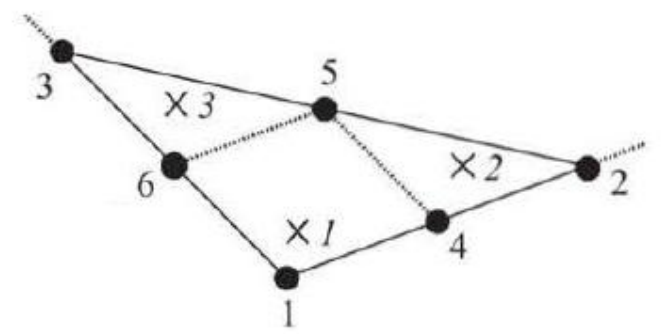

Figure (15) 6-Node Triangular Elements Used in Plates Discretizing

\subsection{FE Model of Gamesa Tower and Foundation-Soil System in PLAXIS 3D}

Seismic analysis for the wind turbines is conducted at three locations in the project (Zone 6, 7 and 8). The configuration for the wind turbine adopted in the analysis is shown in Table (1). The wind turbine tower and the foundation were modelled using plate elements as can be seen in Figure (16). Meanwhile, the Nacelle was modelled as a volume mass on top of the tower. The material properties assigned to the different components of the wind turbine are presented in Table (2). Mohr Coulomb model was used to simulate the subsurface layers at the project location. The geotechnical parameters for this model were deduced from the field investigation results conducted at the project location as can be seen in Table (3). The properties of the final updated model were adopted for the numerical modelling of the tower in PLAXIS 3D [12,13].

Table (1) Gamesa Wind Turbine configuration

\begin{tabular}{|l|l|l|l|c|}
\hline Structure & Property & Value & Property & Value \\
\hline \multirow{4}{*}{ Tower } & Material & Steel & Height & $55 \mathrm{~m}$ \\
\cline { 2 - 5 } & Top Diameter & $3 \mathrm{~m}$ & 3ottom Diameter & $6 \mathrm{~m}$ \\
\cline { 2 - 5 } & Wall Thickness & $2.1 \mathrm{~cm}$ & Total Weight & $620 \mathrm{kN}$ \\
\hline \multirow{2}{*}{ Foundation } & Material & Concrete & Shape & Circular \\
\cline { 2 - 5 } & Diameter & $18 \mathrm{~m}$ & Thickness & $2.5 \mathrm{~m}$ \\
\hline \multirow{2}{*}{$\begin{array}{l}\text { elle, Rotor Hub } \\
\text { and Blades }\end{array}$} & Nacelle Height & $3.5 \mathrm{~m}$ & Nacelle Length & $14 \mathrm{~m}$ \\
\cline { 2 - 5 } & Nacelle Width & $3 \mathrm{~m}$ & Total Weight & $430 \mathrm{kN}$ \\
\hline
\end{tabular}


AMBIENT VIBRATION TEST AND NUMERICAL MODELLING OF WIND TURBINE TOWERS INCLUDING SOIL STRUCTURE INTERACTION

Table (2) Gamesa Wind Turbine material properties

\begin{tabular}{|c|c|c|c|c|c|}
\hline Structure & Property & Value & Property & \multicolumn{2}{|c|}{ Value } \\
\hline \multirow[t]{4}{*}{ Tower } & Element Type & Plate Element & Thickness & \multicolumn{2}{|c|}{$\begin{array}{l}\text { iable as updated } \\
\text { el in OPENSEES }\end{array}$} \\
\hline & asticity Modulus & $2 \times 10^{8} \mathrm{kPa}$ & Poisson's Ratio & \multicolumn{2}{|c|}{0.26} \\
\hline & \multirow[t]{2}{*}{ Unit Weight } & \multirow[t]{2}{*}{$78.5 \mathrm{kN}$} & \multirow{2}{*}{$\begin{array}{l}\text { yleigh's Damping } \\
\text { Parameters }\end{array}$} & $\alpha$ & 1257 \\
\hline & & & & $\beta$ & $66 \times 10^{-6}$ \\
\hline \multirow[t]{4}{*}{ Foundation } & Element Type & Plate Element & Thickness & \multicolumn{2}{|c|}{$1.5 \mathrm{~m}$} \\
\hline & asticity Modulus & $22 \times 10^{7} \mathrm{kPa}$ & Poisson's Ratio & \multicolumn{2}{|c|}{0.20} \\
\hline & \multirow[t]{2}{*}{ Unit Weight } & \multirow[t]{2}{*}{$25 \mathrm{kN}$} & \multirow{2}{*}{$\begin{array}{l}\text { yleigh's Damping } \\
\text { Parameters }\end{array}$} & $\alpha$ & 04189 \\
\hline & & & & $\beta$ & $22 \times 10^{-6}$ \\
\hline \multirow{2}{*}{$\begin{array}{l}\text { elle, Rotor Hub } \\
\text { and Blades }\end{array}$} & Element Type & olume Element & Total Weight & \multicolumn{2}{|c|}{$430 \mathrm{kN}$} \\
\hline & asticity Modulus & $2 \times 10^{8}$ & Poisson's Ratio & \multicolumn{2}{|c|}{0.26} \\
\hline
\end{tabular}

\subsection{Seismic Analysis in PLAXIS 3D}

To simulate the earthquake motion of Al Aqaba Earthquake 1995 as shown previously in Figure (4), prescribed acceleration was placed at the lower boundary of the model. This prescribed acceleration has components in $\mathrm{X}, \mathrm{Y}$ and $\mathrm{Z}$ directions to simulate the earthquake motion in the three dimensions. To limit wave reflection from the vertical boundaries inside the model, the vertical boundaries were placed as far as $30 \mathrm{~m}$ from the foundation edges. Moreover, special viscous boundaries were used to absorb upcoming stress waves and further reduce wave reflections $[11,12,13]$.

\subsection{Analysis Results of Zafarana Zone (6)}

Seismic analysis for Zone 6 has shown that the maximum expected lateral displacement at the top of the wind turbine does not exceed $31 \mathrm{~mm}$. Moreover, Figure (17) shows the moments on the wind turbine body generated by the seismic motion.

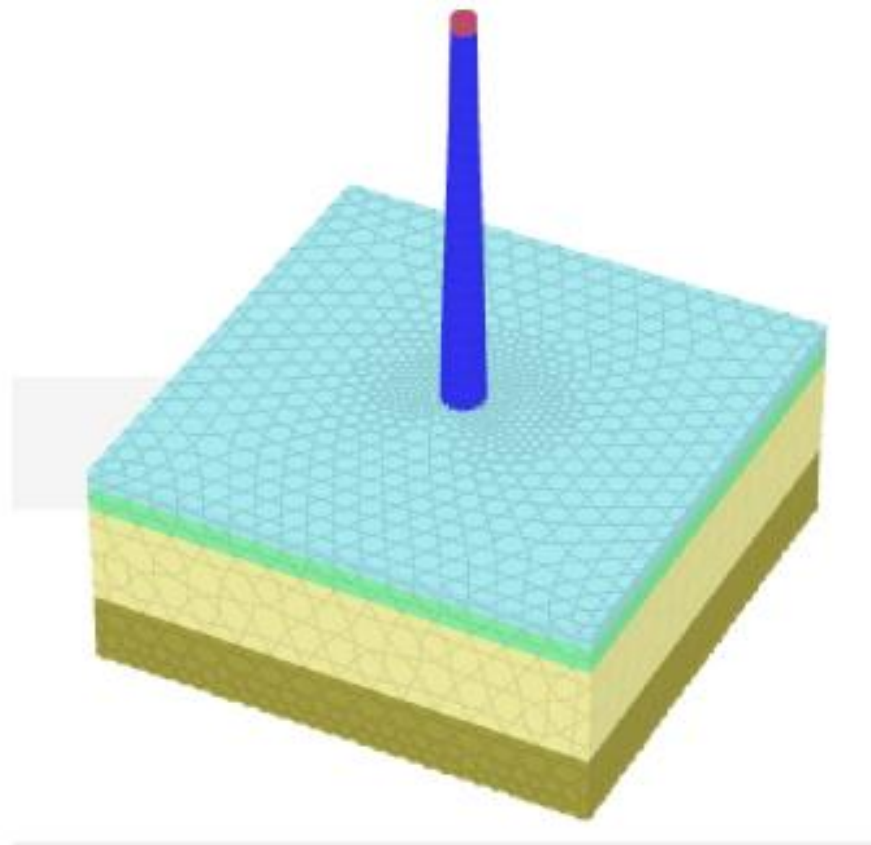

Figure (16) Wind turbine model built for Zafarana zone (6) 
AMBIENT VIBRATION TEST AND NUMERICAL MODELLING OF WIND TURBINE TOWERS INCLUDING SOIL STRUCTURE INTERACTION

Table (3) Properties of Soil and Rock Formations Used in the Finite Element Model

\begin{tabular}{|c|c|c|c|c|c|c|c|}
\hline \multirow[t]{2}{*}{ Zone } & \multirow[t]{2}{*}{ er Thickness } & \multicolumn{2}{|c|}{ ir Strength Parameter } & \multicolumn{2}{|c|}{ Elastic Parameters } & \multicolumn{2}{|c|}{ Rayleigh Damping } \\
\hline & & C (kPa) & $\phi$ & E (MPa) & $\mathrm{v}$ & $\alpha$ & $\beta$ \\
\hline \multirow[t]{4}{*}{ one 6} & 2.5 & $\mathbf{0}$ & 37 & 40 & 0.35 & $\mathbf{x 1 0 - 3}$ & $2 \times 10-6$ \\
\hline & 3.5 & $\mathbf{0}$ & 37 & 40 & 0.35 & x10-3 & $2 \times 10-6$ \\
\hline & 12.8 & 100 & $\mathbf{0}$ & 30 & 0.45 & $x 10-3$ & $2 \times 10-6$ \\
\hline & 11.2 & 250 & $\mathbf{0}$ & 90 & 0.23 & x10-3 & $2 \times 10-6$ \\
\hline \multirow[t]{4}{*}{ one 7} & 3.7 & $\mathbf{0}$ & 37 & 40 & 0.35 & $\mathrm{x} 10-3$ & $2 \times 10-6$ \\
\hline & 6.3 & 100 & $\mathbf{0}$ & 30 & 0.45 & x10-3 & $2 \times 10-6$ \\
\hline & 8.8 & 250 & $\mathbf{0}$ & 90 & 0.23 & x10-3 & $2 \times 10-6$ \\
\hline & 11.2 & 250 & $\mathbf{0}$ & 90 & 0.23 & x10-3 & $2 \times 10-6$ \\
\hline \multirow[t]{4}{*}{ tone 8} & 3.7 & $\mathbf{0}$ & 37 & 40 & 0.35 & $\mathbf{x 1 0 - 3}$ & $2 \times 10-6$ \\
\hline & 6.3 & $\mathbf{0}$ & 37 & 40 & 0.35 & $\mathrm{x} 10-3$ & $2 \times 10-6$ \\
\hline & 8.8 & 100 & $\mathbf{0}$ & 30 & 0.45 & x10-3 & $2 \times 10-6$ \\
\hline & 11.2 & 250 & $\mathbf{0}$ & 90 & 0.23 & x10-3 & $2 \times 10-6$ \\
\hline
\end{tabular}

Figure (17) Bending moments on the wind turbine due to seismic action at Zafarana 6

\subsection{Results Discussion of Zafarana Zone (6)}

Seismic analysis for Zone 6 has shown that the maximum expected lateral displacement at the top of the wind turbine does not exceed $31 \mathrm{~mm}$. This value is considered to be very low and within the safe limits, considering the wind turbine height and geometry. Moreover, Figure (17) shows the moments on the wind turbine body generated by the seismic motion. For M11 and M22, the maximum moment generated on the wind turbine body does not exceed 80 $\mathrm{kN} . \mathrm{m} / \mathrm{m}$. Meanwhile the moment generated on the wind turbine foundation may reach up to $680 \mathrm{kN} . \mathrm{m} / \mathrm{m}$. Moreover, for M12 the moment on the wind turbine body does not exceed 40 $\mathrm{kN} . \mathrm{m} / \mathrm{m}$ while the moment on the wind turbine foundation may reach up to $180 \mathrm{kN} . \mathrm{m} / \mathrm{m}$. Where is safe according the reinforced concrete capacity and dimensions in the wind turbine towers at Zafarana Zone (6).

\section{CONCLUSIONS}

1. This work presents one of the pioneer studies concerning the investigation of the structural dynamic performance of a full-scale wind turbine tower of Gamesa G52 including soil structure interaction and under seismic load in Egypt.

2. In ambient vibration test the dynamic characteristics of the towers were extracted using EFDD and SSI-CVA methods. It can be deduced that both methods are successful in determining the modal properties of the full-scale wind turbine towers. However SSI method was more powerful in identifying the first side to side bending mode at 0.259 $\mathrm{Hz}$ of Gamesa tower which couldn't be identified using EFDD method.

3. Both bending and torsion structural modes of the towers were successfully identified in the range $0-25 \mathrm{~Hz}$. The dynamic behavior of wind towers is characterized by close bending modes in the lower frequency range up to $3 \mathrm{~Hz}$.

4. Seismic analysis for Zone 6 has shown that the maximum expected lateral displacement at the top of the wind turbine does not exceed $31 \mathrm{~mm}$. This value is considered to be very low and within the safe limits, considering the wind turbine height and geometry.

5. The moments on the wind turbine body generated by the seismic motion including soil structure interaction may reach up to $680 \mathrm{kN} . \mathrm{m} / \mathrm{m}$ on wind turbine tower foundation , where it safe and does not exceed the limit.

6. It is suggest according to the final result of the full dynamic analysis of wind turbine towers that, The Egyptian loads code (No. 201) version 2012 can used for the seismic loads in comparison with the fully dynamic analysis using PLAXIS 3D, and also, it can be applied to wind turbine tower considering the approach of wind tower parameters to chimney ones.

7. The final model of the tower represents a reliable baseline model that can be utilized in further numerical studies under different loading conditions including wind loads and different soil types under the wind turbine towers. 
(STDF) for funding this research project in the context of ongoing joint US- Egypt research "Seismic risk assessment of wind turbine towers in Zafarana wind farm Egypt", Project ID:4588. Results shown here are part of the work performed in $3^{\text {rd }}$ progress report.

\section{REFERENCES}

1. Moustafa, A.,Khalil, M.(1994) Rejuvenation of the eastern Mediterranean passive continental margin in northern and central Sinai: new data from the Themed Fault, Geological Magazine, Vol. 131, Issue 04, pp.435-448.

2. Abdel-aal, A., Kamal, H., Abdelhay, M., and Elzahaby, K. (2015) "Probabilistic and stochastic seismic hazard assessment for wind turbine tower sites in Zafarana Wind Farm, Gulf of Suez, Egypt,Bulletin of Engineering Geology and the Environment.

3. Yann Klinger,Y., Rivera, L., Haessler, H., and Maurin, J. (1999) Active Faulting in the Gulf of Aqaba: New Knowledge from the Mw 7.3 Earthquake of 22 November 1995, Bulletin of the Seismological Society of America, Vol. 84, Issue 04, pp.1025-1036.

4. The Egyptian loads code, No.201 (2012)Housing and Building National Research Center, Egypt.

5. K. Kandil, G. Saudi, B. Eltaly, and M. M. Abo El-Khier (in press) Seismic response of a full-scale wind turbine tower using experimental and numerical modal analysis, International Journal of Advanced Structural Engineering.

6. M. M. Abo El-Khier (2015) Simulating the dynamic behavior of the wind turbine tower using ambient vibration testing, MSc thesis, Civil Engineering Department, Faculty of Engineering, Menoufia University, Menoufia, Egypt.

7. G. Saudi, and H. Kamal (2014) Ambient vibration testing of full- scale wind turbine tower, the 10th International Conference on the Role of Engineering Towards A Better Environment Intelligent Environmental Engineering: From Vision to Action, Alexandria, Egypt.

8. K. Abdel-Raheem, S. Abdel Raheem,H.Soghair, and M.Ahmed (2010) Evaluation of $\backslash$ seismic performance of multistory buildings designed according to Egyptian Code, Journal of Engineering Sciences, Assiut University, Vol. 38, No. 2, pp. 381-402.

9. S. Mahmoud, and W. Abdallah (2014) Response analysis of multi-story RC buildings under equivalent static and dynamic loads according to Egyptian code, International Journal of Civil and Structural Engineering Research, Vol. 2, No. 1, pp. 79-88.

10. Structural Vibration Solutions ApS. (2012) ARTeMIS Extractor, Denmark, 1422.

11. PLAXIS 3D (2015) PLAXIS 3D Reference Manual, Anniversary Edition.

12. Miceli, F. (2013) Wind Turbines Precast Foundations. Towers and Foundation,http://www.windfarmbop.com/wind-turbines-precast-foundations./

13. Morgan, K. and Ntambakwa, E. (2008) Wind Turbine Foundation Behavior and Design Considerations, AWEA Windpower Conference, Houston. 